Original Research Paper

\title{
Basalt as Pozzolana and Filler in Ordinary Portland Cement
}

\author{
${ }^{1}$ H. El-Didamony, ${ }^{1}$ I.M. Helmy, ${ }^{2}$ Randa M. Osman and ${ }^{1}$ A.M. Habboud \\ ${ }^{1}$ Faculty of science, Zagazig University, Zagazig, Egypt \\ ${ }^{2}$ Department of Chemical Engineering and Pilot Plant, National Research Centre, Cairo, Egypt
}

\author{
Article history \\ Received: 17-04-2015 \\ Revised: $12-05-2015$ \\ Accepted: 16-06-2015 \\ Corresponding Author: \\ Randa M. Osman \\ Department of Chemical \\ Engineering and Pilot Plant, \\ National Research Centre, Cairo, \\ Egypt \\ Email:randa.osman2015@hotmail.com
}

\section{Introduction}

A pozzolana is a material, which is capable of reacting with $\mathrm{Ca}(\mathrm{OH})_{2}$, in the presence of water at ordinary temperatures to form compounds have cementitious properties (as C-S-H gel) (Massazza, 2006). Nowadays, different types of mineral admixtures are added to clinker during the milling process or directly to the cement. The pozzolanic materials used in the cement industry, including pozzolanic (natural pozzolana, low calcium fly ash, silica fume), autopozzolanic (high calcium fly ash and blast furnace slag) and crystalline materials (as a filler) (Siddique and Klaus, 2009; Martinez-Reyes et al., 2010), some of which interact physically and/or chemically with Portland cement or its hydration products (Rahhal et al., 2012; Jain, 2012). The performance of mineral admixtures in blended cements and concrete depends on some factors such as particle size distribution, specific surface area, chemical composition and crystallinity (Massazza, 2006; Siddique and Klaus, 2009; MartinezReyes et al., 2010; Rahhal et al., 2012; Jain, 2012;

\begin{abstract}
Pozzolana is defined as a siliceous or siliceous and aluminous materials which in itself possess little or no cementing properties, but will $\mathrm{Ca}(\mathrm{OH})_{2}$ at ordinary temperature to form compound possessing cementious properties. Pozzolanic cement contains Portland cement as one of their main components in addition to natural or industrial by etc. The aim of the present investigation is to study the effect of fresh basalt on the properties of ordinary Portland cement pastes. The rate of hydration was studied from the determination of free lime, combined mechanical properties such as bulk density, apparent porosity and compressive strength of the hardened cement pastes were determined. other side, the combined water increases with the basalt content and curing time. This is mainly due to the effect of nucleating of basalt as fller. The addition of $20 \mathrm{wt} \%$ basalt gives the higher compressive strength of the cement pastes in comparison to OPC and cement pastes
\end{abstract}

Keywords: Basalt, Pozzolana, Compressive Strength, DTA, XRD
Uzal et al., 2010). Mineral admixtures are widely used in concrete to improve the physical and chemical properties or to reduce the costs and saving of energy. The using of cement replacement materials may reduce the factors related to declining concrete durability or to improve its resistance against sulfate attack (Ghrici et al., 2007; Yeau and Kim, 2005; Shui et al., 2010; Hossain and Lachemi, 2006; 2007). Also, mineral additions have improved the strength by filling of the pores and change its diameter and distribution (De Weerdt et al., 2011). One of the observed disadvantages of the used natural pozzolana in cement is decreasing the early strength. Natural pozzolana have been widely used in blended cement for many applications (Binici et al., 2007a; Habert et al., 2008), some of them are pyroclastic rocks that are containing siliceous, or siliceous and aluminous volcanic glass (Hossain, 2005; Binici et al., 2007b; Uzal and Turanl, 2012).

Basalt is one of igneous rock, which was formed during the cooling of magma in the old ages of the earth. Most of igneous minerals are present in active state and that are changed under environment 
conditions, physical or chemical weathering, into more stable clay minerals (Constantiner and Diamond, 2003). The effect of limestone powder, basalt powder and marble powder as mineral admixtures on the fresh and hardened properties of self compacting concrete was investigated (Uysal and Yilmaz, 2011). The basalt as a mineral admixture was investigated, where the physical properties and chemical compositions were studied (Laibao et al., 2013; Saraya, 2011). The effect of basaltic pumice on the mechanical and physical properties (Kelestemur and Demirel, 2010; Binic et al., 2014) and the seawater resistance of the concrete was studied (Binici et al., 2008). Also, the deterioration effect of blended cement combinations with Red Brick Dust (RBD) and Ground Basaltic Pumice (GBP) was investigated (Binici et al., 2012).

This study is aimed to investigate the influence of basalt up to $20 \%$ on the physicochemical properties of cement pastes.

\section{Experimental}

The starting materials used were Portland cement and fresh basalt (A bou-Zaabal, Cairo, Egypt). Table 1 shows the chemical analysis of these materials. The basalt was ground to pass $90 \mu \mathrm{m}$ sieve and the fineness of cement was $3250 \pm 50 \mathrm{~cm}^{2} / \mathrm{g}$.

The XRD pattern of basalt is shown in Fig. 1. the pattern indicates that it is fresh basalt and composed mainly of the calcia-soda plagioclase feldspar mineral albite and the calcic pyroxene mineral augite. This is in agreement with the XRF analysis of basalt which shows that basalt contains $9.68 \% \mathrm{CaO}$ and $3.06 \% \mathrm{Na}_{2} \mathrm{O}$.

The mix composition of the prepared basalt- filled cement is shown in Table 2. Each dry mix was homogenized in a porcelain ball mill for one hour using a mechanical roller to obtain complete homogeneity. The water of consistency, initial and final setting times of each blend were determined according to ASTM specification (ASTM, 2006). The pastes were moulded in $2.54 \times 2.54 \times 2.54 \mathrm{~cm}$ cubic moulds, cured in humidity chamber at $100 \%$ relative humidity at constant temperature of $23 \pm 2^{\circ} \mathrm{C}$ for the first $24 \mathrm{~h}$. The samples were demoulded and then, cured under water until the desired curing time up to 90 days. After any hydration period, the dried samples were stored in air-tight bottles to prevent carbonation.

The water of consistency and the initial as well as final setting times were determined. The bulk density and total porosity was carried out before the specimens subjected to compressive strength. The chemically combined water content was determined by the ignition of the paste at $950^{\circ} \mathrm{C}$ for one hour, the free lime and insoluble residue were determined. The hydration kinetic was also followed by the aid of DTA and IR techniques.

\section{Results and Discussions}

\section{Effect of Basalt on the Physico-Mechanical and Chemically Properties of Cement Pastes}

The degree of hydration was measured by the determination of chemically combined water, free lime and insoluble matter contents. Other phsico-chemical properties such as the water of consistency, initial and final setting times, bulk density as well as total porosity and compressive strength of cement pastes were determined for the hardened cement pastes

\section{Water of Consistency and Setting Time}

The water of consistency of initial and final setting times of the basalt- filled cement pastes made from OPC and basalt as a function of basalt content are graphically plotted in Fig. 2. evidently the partial substitution of ordinary Portland cement by basalt decreases the amount of water of consistency of cement pastes. Also, as the amount of basalt increases the water of consistency decreases due to the unhydraulic properties of basalt in comparison to Portland cement. The basalt has no or very little pozzolanic activity, therefore, it needs less water for gauging and then the water of consistency decreases with the basalt content. The initial and final setting time of basalt filled cement pastes elongate linearly with the basalt content. This is mainly also due to the low hydraulic properties of basalt as compared with Portland cement. The basalt does not take some extent in initial hydration as Portland cement. As the cement content decreases the setting times are elongated, i.e., the dilution of cement with basalt leads to delaying the reaction.

\section{Chemically Combined Water}

The degree of hydration of cement paste may be estimated by the determination of the combined water of the blended cement paste. The definite chemical composition of different hydrates as well as the changes caused by pozzolana in their chemical composition is not accurately known. Accordingly the determination of combined water is far useful in determining the degree of hydration of pozzolanic cement.

The chemically combined water contents of OPC as well as basalt filled cement pastes are graphically plotted as a function of curing time up to 90 days in Fig. 3. It can be observed that the combined water contents increase gradually with curing time for all hardened cement pastes due to the progress of hydration. Generally, basalt-filled cement pastes give lower combined water contents than those of ordinary Portland cement pastes at all curing ages. Also, as the basalt content increases the chemically combined water content decreases. This is mainly due to the less pozzolanic activity, or nearly no 
pozzolanic activity of basalt. Therefore, the combined water content decreases with the decrease of the amount of Portland cement which is the main factor of the hydration of pozzolanic cement pastes.

Table 1. Chemical analysis of the starting materials, mass $\%$

\begin{tabular}{lllllllllll}
\hline Oxide Materials & $\mathrm{SiO}_{2}$ & $\mathrm{Al}_{2} \mathrm{O}_{3}$ & $\mathrm{FeO}_{2}$ & $\mathrm{CaO}$ & $\mathrm{MgO}$ & $\mathrm{SO}_{3}$ & $\mathrm{Na}_{2} \mathrm{O}$ & $\mathrm{K}_{2} \mathrm{O}$ & LOI $^{*}$ & Total \\
\hline Basalt & 59.74 & 15.39 & 11.40 & 9.68 & 1.87 & - & 0.06 & 6.24 & 1.52 & 99.93 \\
OPC & 20.82 & 4.63 & 3.30 & 60.63 & 1.59 & 3.14 & 0.24 & 0.18 & 4.21 & 99.99 \\
\hline
\end{tabular}

Table 2. Mix composition of the investigated mixes, (wt $\%$ )

\begin{tabular}{lrr}
\hline Basalt & OPC & Sample. No. \\
\hline 0 & 100 & OPC \\
5 & 95 & B1 \\
10 & 90 & B2 \\
15 & 85 & B3 \\
20 & 80 & B4 \\
\hline
\end{tabular}

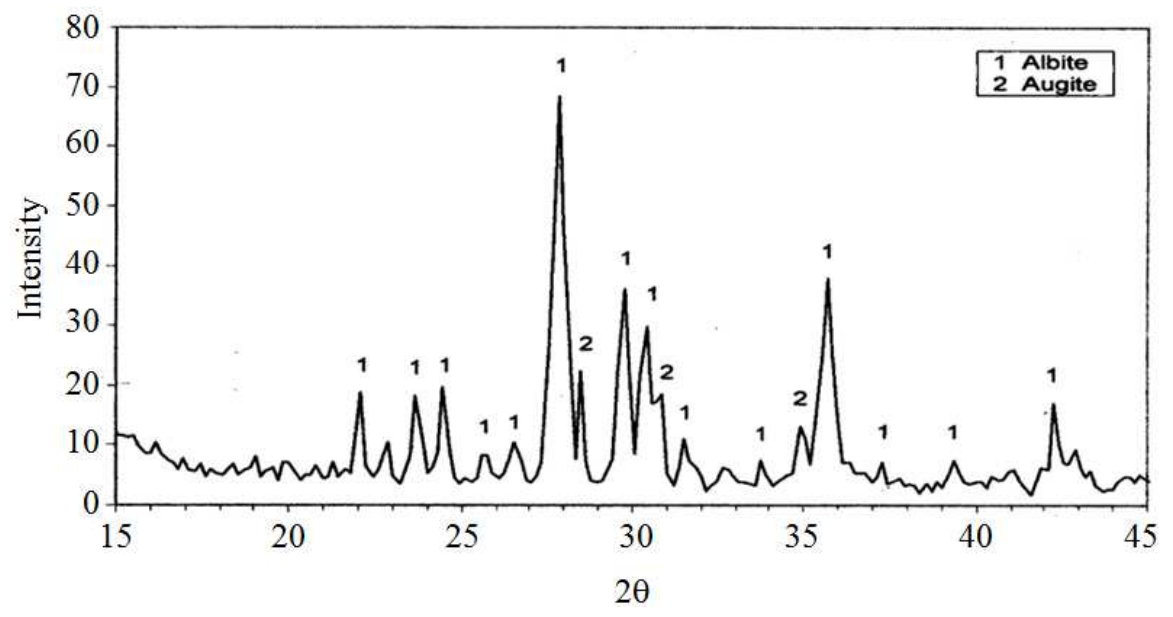

Fig. 1. XRD pattern of basalt

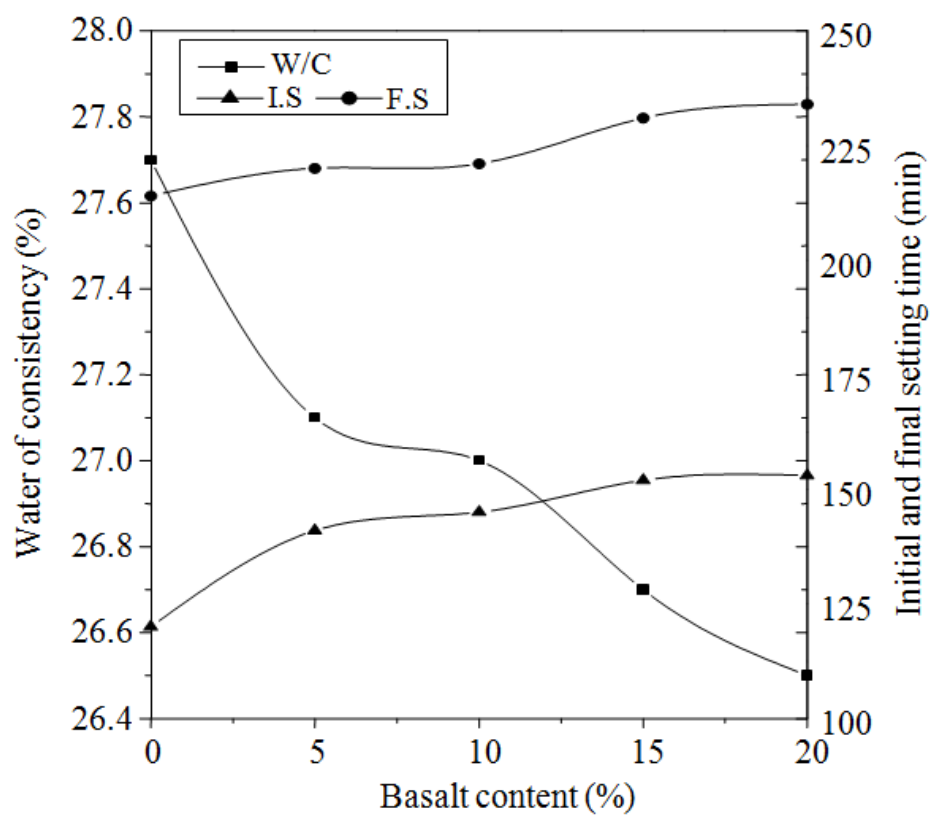

Fig. 2. Water of consistancy initaland final setting time of OPC and pozzolanic cement pastes with 5, 10, 15 and $20 \%$ basalt 


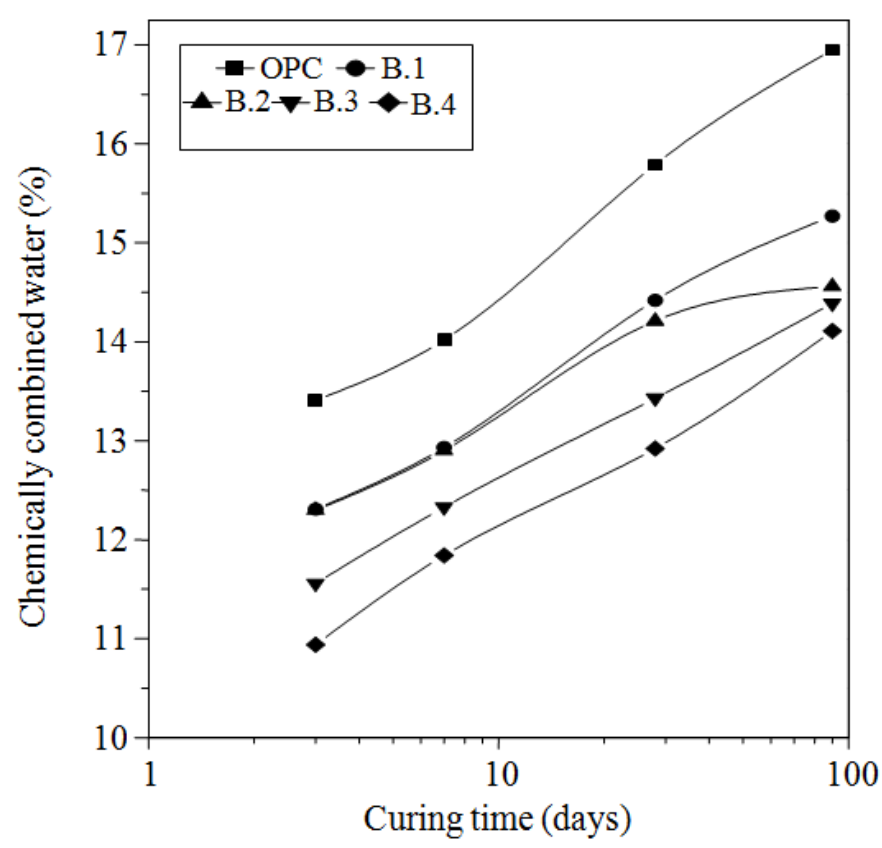

Fig. 3. Chemicall combined water content of OPC and pozzolanic cement as funcation of curring time

The decrease of the combined water content with the amount of substituted basalt is also due to the decrease of the water of consistency of the cement paste. As the mixing water increases the rate of hydration of cement paste increases.

\section{Free Lime Content}

The free lime contents of OPC and basalt filled cement pastes cured for 3, 7, 28 and 90 days are graphically plotted as a function of curing time up to 90 days in Fig. 4. It is clear that the free lime content increases with curing time for all cement pastes such as OPC as well as basalt cement pastes. This means that the basalt has no pozzolanic activity but it behaves as filler. Therefore, this type of cement is called filled-cement. The free lime increases for all basalt cement at three days; this is mainly due to the nucleating effect of the basalt which accelerates the rate of hydration of cement pastes. Therefore and the cement pastes liberate more hydrated lime than OPC paste. As the amount of basalt increases on the expense of ordinary Portland cement up to $15 \mathrm{wt} \%$, the liberated lime increases for all curing times up to 90 days. At $20 \mathrm{wt} \%$ basalt the free lime is lower than that of $15 \mathrm{wt} \%$ basalt at all curing times. This is mainly due to the decrease of the amount of Portland cement which is the main source of liberated lime. There is a decrease of free lime contents of the filled cement pastes containing basalt up to $15 \mathrm{wt} \%$ after 90 days. This may be due to some of pozzolanic activity of basalt at latter ages of hydration, due to the increase $\mathrm{OH}^{-}$ions at latter ages from the liberated $\mathrm{Ca}(\mathrm{OH})_{2}$.

\section{Phase Composition}

\section{Differential Thermal Analysis}

Figure 5 shows the DTA thermogrames of the hydrated sample of OPC with $20 \mathrm{wt} \%$ basalt as a function of curing time $(3,7,28$ days). The thermogrames illustrate endotherms at $150^{\circ} \mathrm{C}, 400-500^{\circ} \mathrm{C}$ and $800^{\circ} \mathrm{C}$. The first endothermic peak is due to the decomposition of calcium silicate and calcium aluminate hydrates. The second endothermic peak represents the decomposition of $\mathrm{Ca}(\mathrm{OH})_{2}$. In addition, the third peak is due to the decomposition of calcium carbonate $\mathrm{CaCO}_{3}$, respectively. It can be seen that, the peak area of $\mathrm{CSH}$ as well as CAH or CSAH increase with time due to the progress of hydration of the four major phases of Portland cement such as $\mathrm{C}_{3} \mathrm{~S}, \mathrm{~B}-\mathrm{C}_{2} \mathrm{~S}, \mathrm{C}_{3} \mathrm{~A}$ and $\mathrm{C}_{4} \mathrm{AF}$ as well as the pozzolanic reaction. The peak area of $\mathrm{Ca}$ $(\mathrm{OH})_{2}$ increases with time. This means that the basalt has no pozzolanic activity but it behaves as filler which can accelerate the rate of hydration.

Figure 6 shows the DTA thermograms of the hydrated samples of OPC, 10, $20 \mathrm{wt} \%$ basalt at 28 days. The thermograms illustrate endotherms at $105^{\circ} \mathrm{C}, 400-500^{\circ} \mathrm{C}, 800^{\circ} \mathrm{C}$. The first endothermic peak is due to the decomposition of calcium silicate as well as calcium sulphoaluminate hydrate. The second endothermic peak represents the decomposition of $\mathrm{Ca}$ $(\mathrm{OH})_{2}$. In addition, the third peak is due to the decomposition of calcium silicate $\mathrm{CaCO}_{3}$, respectively. It can be seen that the peak area of $\mathrm{CSH}$ and sulphoaluminate increases with the amount of 
substitution basalt. As the mixing water of increases the rate of hydration of cement paste increases. The peak area of $\mathrm{Ca}(\mathrm{OH})_{2}$ increases with basalt content up to 10 $\mathrm{wt} \%$; this is due to that the basalt acts as a nucleating agent. At $20 \mathrm{wt} \%$ basalt, the free lime is lower them that of $10 \mathrm{wt} \%$ basalt at 28 days. This is mainly due to the decrease of the amount of Portland cement which is the main source of liberated lime.

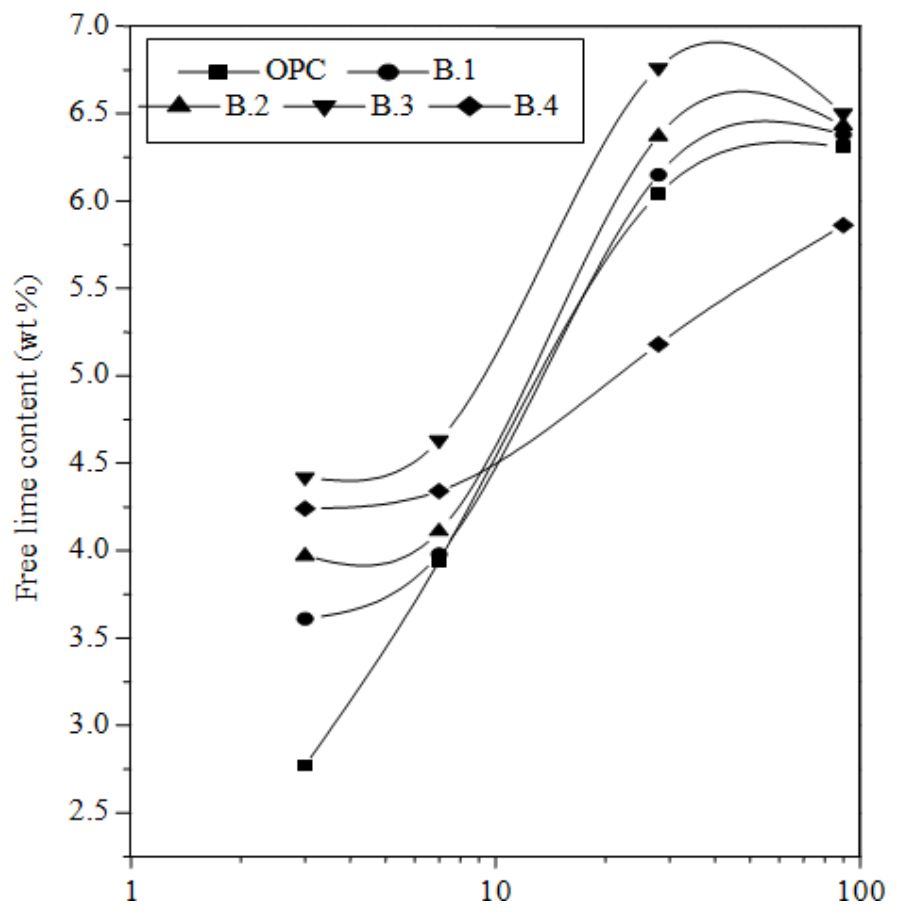

Fig. 4. Free lime content of OPC and pozzolanic cement pastes as function of curing time up 90 days

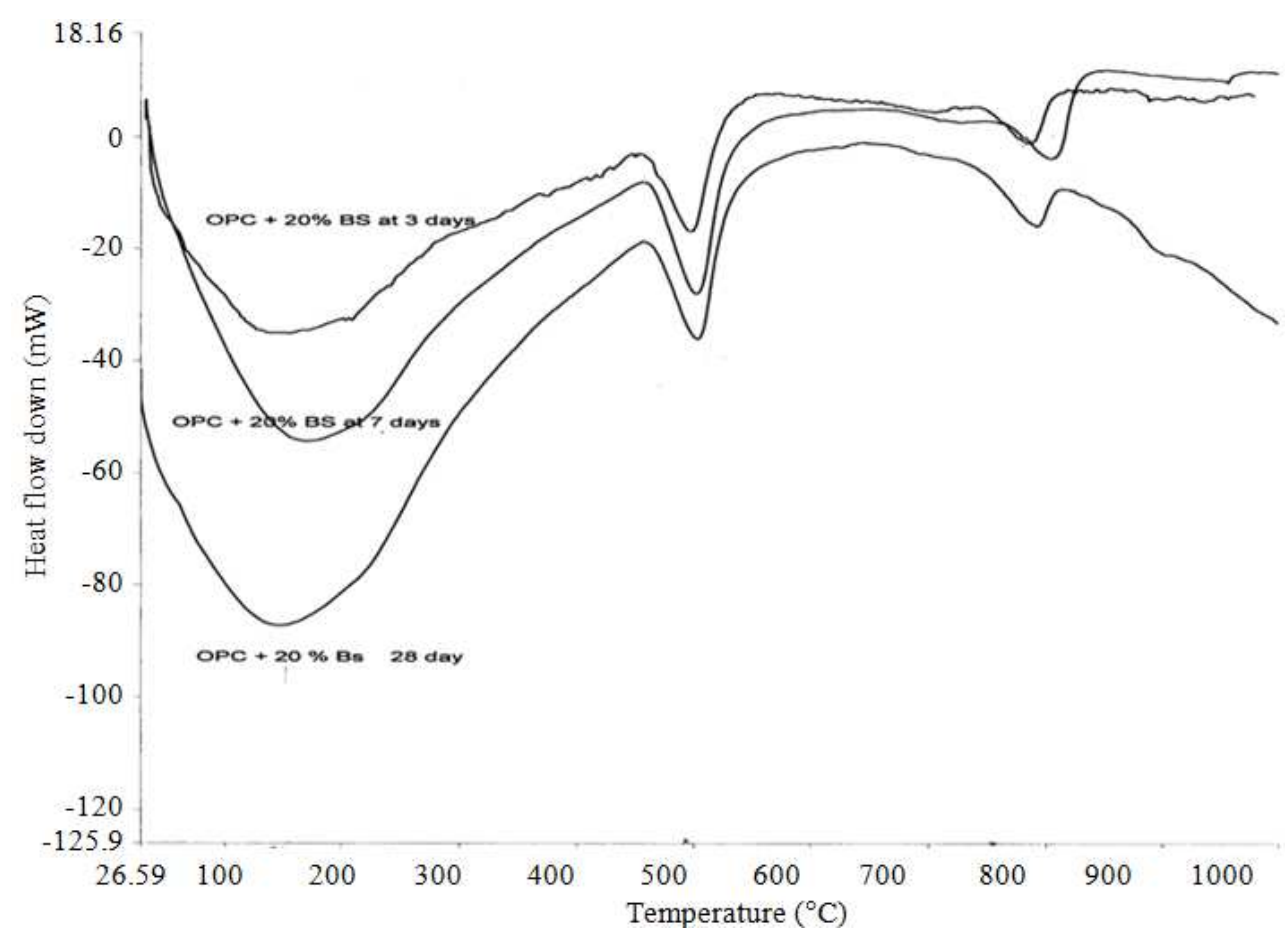

Fig. 5. DTA thermograms of the hydrated samples of OP with $20 \mathrm{wt} \%$ basalt as a function of curing time (3, 7, 28, days) 


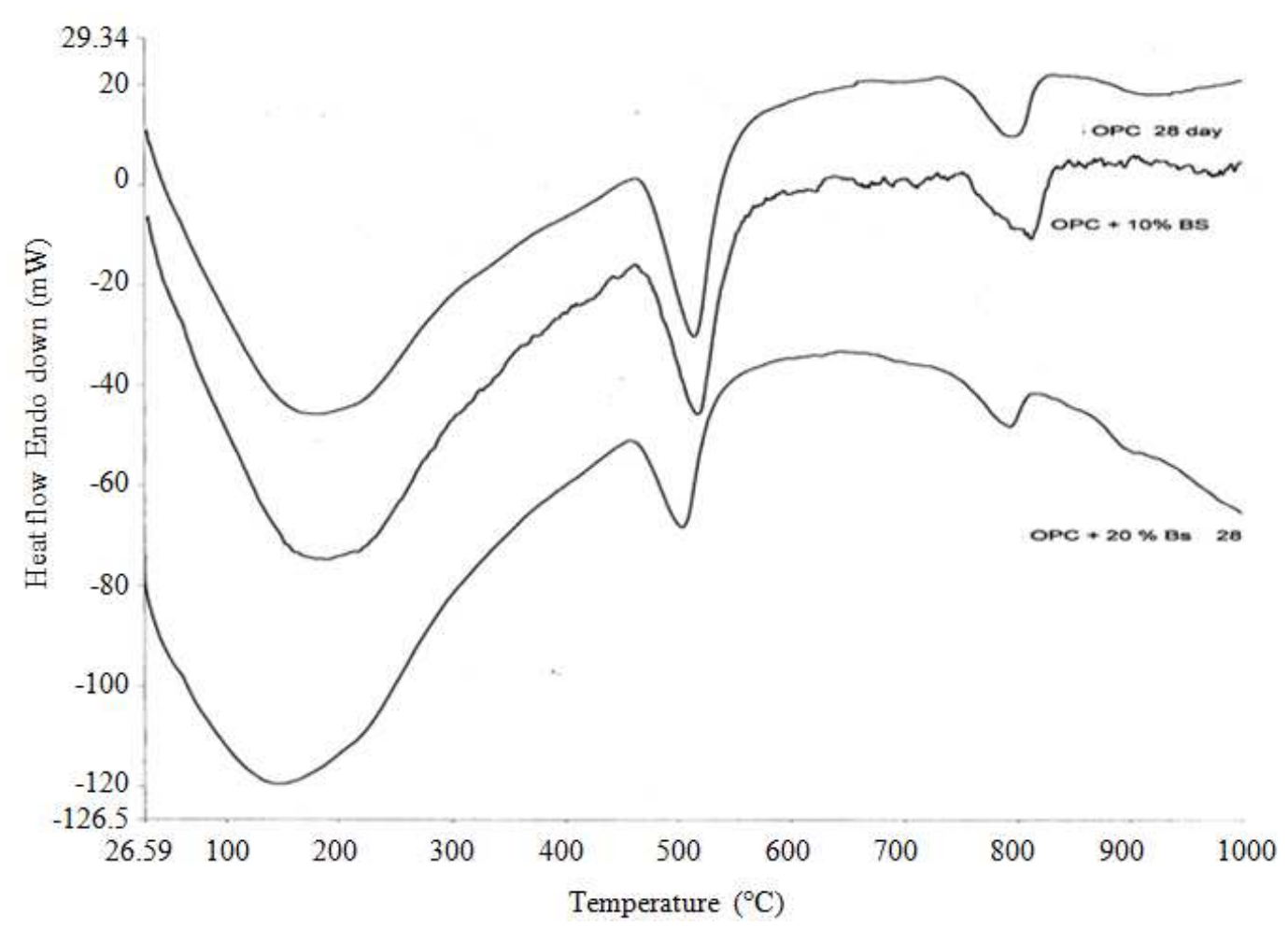

Fig. 6. DTA thermograms of the hydrated samples of OPC, $10,20 \mathrm{wt} \%$ basalt as a function of curing time (28, days)

\section{I.R. Spectroscopy}

Figure 7 shows the infrared spectra of the hydrated samples of $(10,15$ and $20 \mathrm{wt} \%)$ as a function of curing time 3 days. The bands in the region 900-1000 $\mathrm{cm}^{-1}$ are due to silicate group. The Figure shows that absorption band at $1424 \mathrm{~cm}^{-1}$ is due to the presence of carbonate $\left(\mathrm{CaCO}_{3}\right)$ in the sample. The band at 876 $\mathrm{cm}^{-1}$ indicates the formation of $\mathrm{Al}-\mathrm{OH}$ band. The band at $3220 \mathrm{~cm}^{-1}$ decrease with amount of basalt due to the less pozzolanic activity, or nearly no pozzolanic activity of basalt. Therefore, the combined water content decreases with the decrease of the amount of Portland cement which is the main factor of the hydration of pozzolanic cement pastes. This decrease also due to the decrease of the water of consistency of the cement paste. Whereas, the intensity of $\mathrm{Ca}(\mathrm{OH})_{2}$ band at $3644 \mathrm{~cm}^{-1}$ increases up to $15 \mathrm{wt} \%$ due to the nucleating effect of the basalt which accelerates the rate of hydration of cement pastes. At $20 \mathrm{wt} \%$ basalt the $\mathrm{Ca}(\mathrm{OH})_{2}$ is lower than that $15 \mathrm{wt} \%$. This is mainly due to the decrease of the amount of Portland cement which is the main source of liberated lime. I.R.Spectra corresponding to the hydrated samples of Portland cement with $10,15,20 \mathrm{wt} \%$ basalt as a function of curing time 90 days are shown in Fig. 8 The IR-Spectra are nearly the same as in the previous Fig. 7.

\section{Insoluble Residue Contents}

The results of insoluble residue of portland cement and basalt filled-cement pastes as a function of basalt content and curing time are graphically plotted in Figure 9. It is clear that the insoluble residue of all cement pastes decreases with curing time due to the continuous hydrations of Portland cement and may be due to pozzolanic activity of basalt fraction. Ordinary Portland cement pastes gives very low insoluble residue and slightly decreases with curing time. This is mainly due to the absence of any mineral admixtures which are insoluble in acidic and alkaline media. The addition of basalt increases the insoluble reside of cement pastes at all curing times. The decrease of insoluble residue of the basalt- filled cement pastes with time may be due to the reaction of any oxides of basalt with lime, calcium aluminates and/or calcium silicate hydrates forming hydrogenet. This tends to the decrease of the insoluble residue of basalt cement paste with curing time.

\section{Bulk Density}

The results of the bulk density of OPC and basalt filled cement pastes containing 5, 10, 15 and $20 \mathrm{wt} \%$ basalt cured for 3, 7, 28 and 90 days are graphically plotted in Fig. 10. The bulk density for all hardened cement pastes increases with curing time up to 90 days. This is mainly due to the continuous hydration of cement 
pastes forming hydration products which are precipitated in some of the open pores. This leads to the increase of bulk density with curing time. On the other side, as the basalt content increases up to $15 \mathrm{wt} \%$ the bulk density of cement pastes increases. These values are higher than those of ordinary Portland cement pastes due to that the basalt acts as nucleating agent which accelerates the hydration of the filled cement pastes. $20 \mathrm{wt} \%$ basalt as replacement for Portland cement gives lower bulk density than of $15 \mathrm{wt} \%$ cement pastes at all curing times up to 90 days. This is mainly due to the decrease of the amount of Portland cement which gives hydration products in comparison to the basalt with has no or very little pozzolanic reaction. Therefore, the bulk density of cement paste which $20 \mathrm{wt} \%$ basalt gives lower bulk density than of $15 \mathrm{wt} \%$ basalt.

\section{Total Porosity}

The total porosity of pozzolanic filled cement pastes made from OPC and basalt as a function of curing tine up to 90 days are graphically plotted in Fig. 11. It is clear that the total porosity of all cement pastes decreases with curing time up to 90 days. This is mainly due to the continuous hydration of cement pastes forming hydration products precipitated in the open pores of the cement pastes. This leads to the decrease of total porosity of all cement pastes. On the other side, ordinary Portland cement pastes give the higher values of total porosity and also the lower bulk density. As the amount of basalt increases up to $15 \mathrm{wt} \%$ the corresponding total porosity decreases. This is also due to the effect of basalt as nucleating agent which accelerates the hydration of filled cement pastes. The filled cement containing $20 \mathrm{wt} \%$ basalt gives higher porosity than that containing $15 \mathrm{wt} \%$ basalt. This is also due to the decrease of the cement content which affects the hydration and then the amount of hydration products. This leads to decrease the hydration products precipitated in some of the open pores, therefore, the total porosity increases at $20 \mathrm{wt} \%$ with respect to cement containing only $15 \%$ basalt. The results of the total porosity are in good agreement with those of the bulk density of the cement pastes. The porosity depends on the type of cement.

\section{Compressive Strength}

The degree of hydration is an essential step towards understanding the rate of strength development. The compressive strength of Portland as well as basalt filled cement pastes made from OPC and basalt as a function of basalt content and curing time up to 90 days are graphically plotted in Figure 12. The results show that the compressive strength increases for all cement pastes with curing time up to 90 days. As the hydration proceeds more hydration products and cementing materials are formed such as $\mathrm{CSH}$ which is the main source of strength leading to increase the compressive strength of hardened cement pastes. As the amount of basalt increases up to $15 \mathrm{wt} \%$ the corresponding compressive strength decreases.

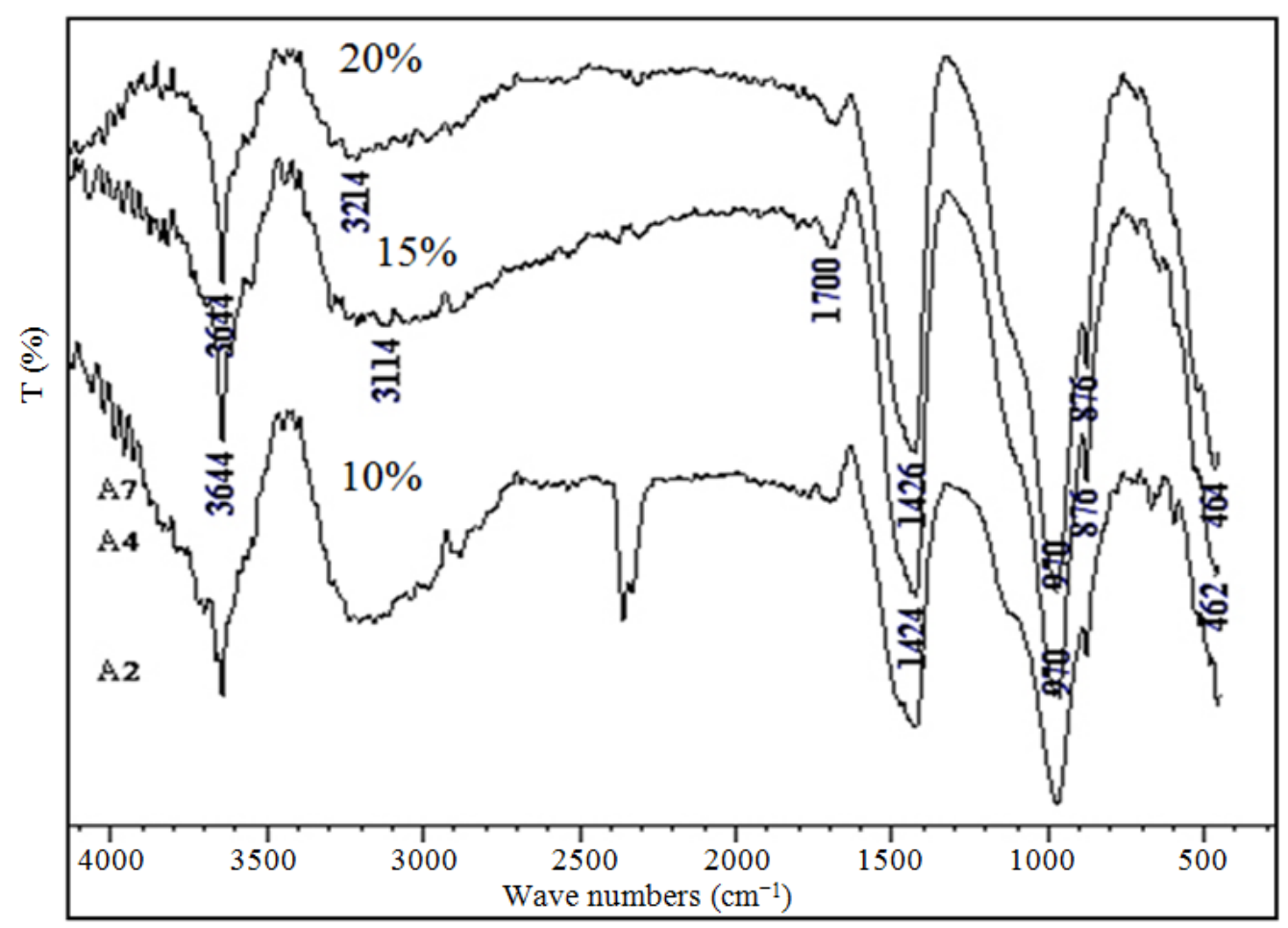

Fig. 7. XRD Pattern of the hydrated samples of OPC with 10,15, $20 \mathrm{wt} \%$ basalt content as a function of curing time 3 days 


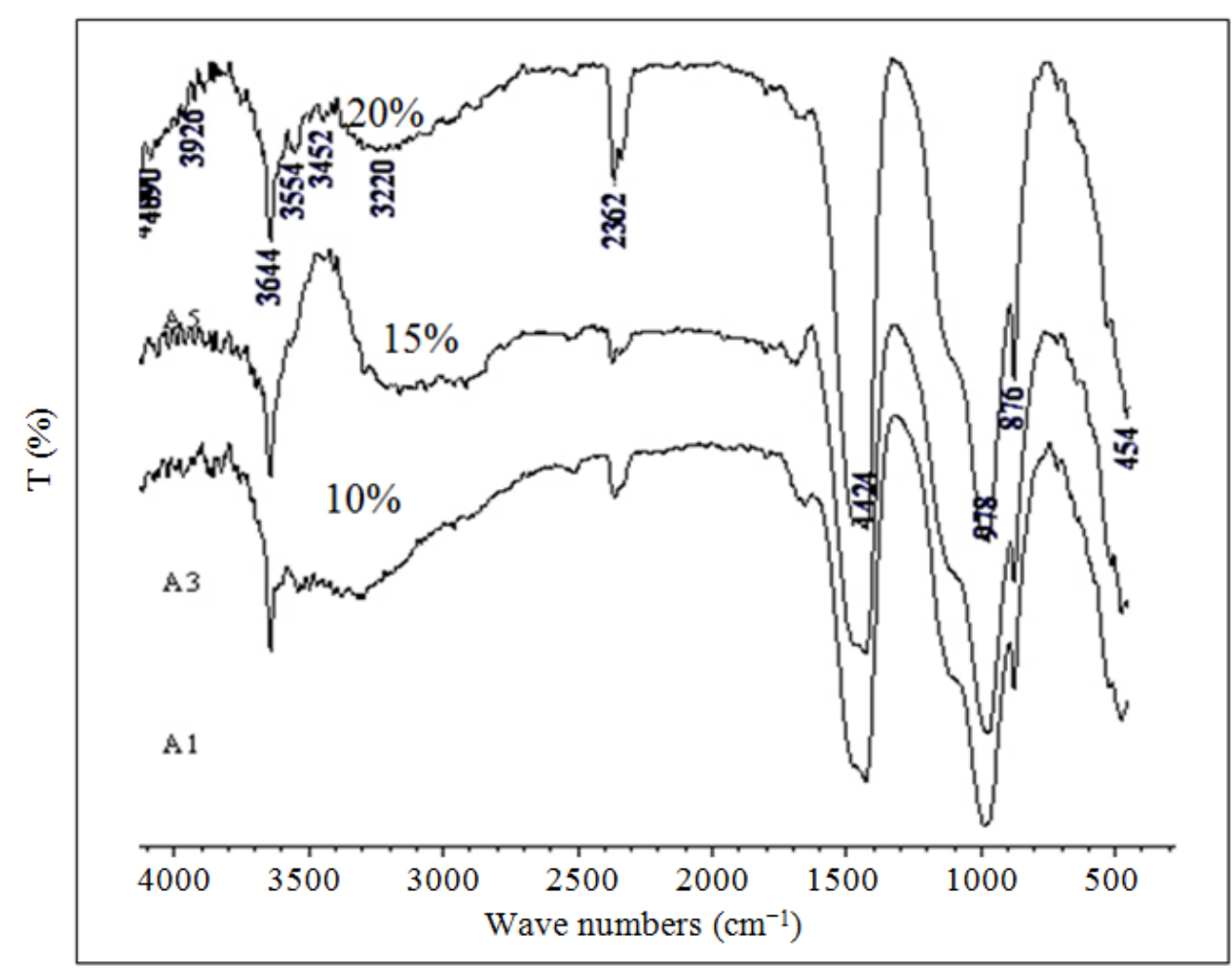

Fig. 8. XRD Pattern of the hydrated samples of OPC with 10, 15, $20 \mathrm{wt} \%$ basalt content as a function of curing time 90 days

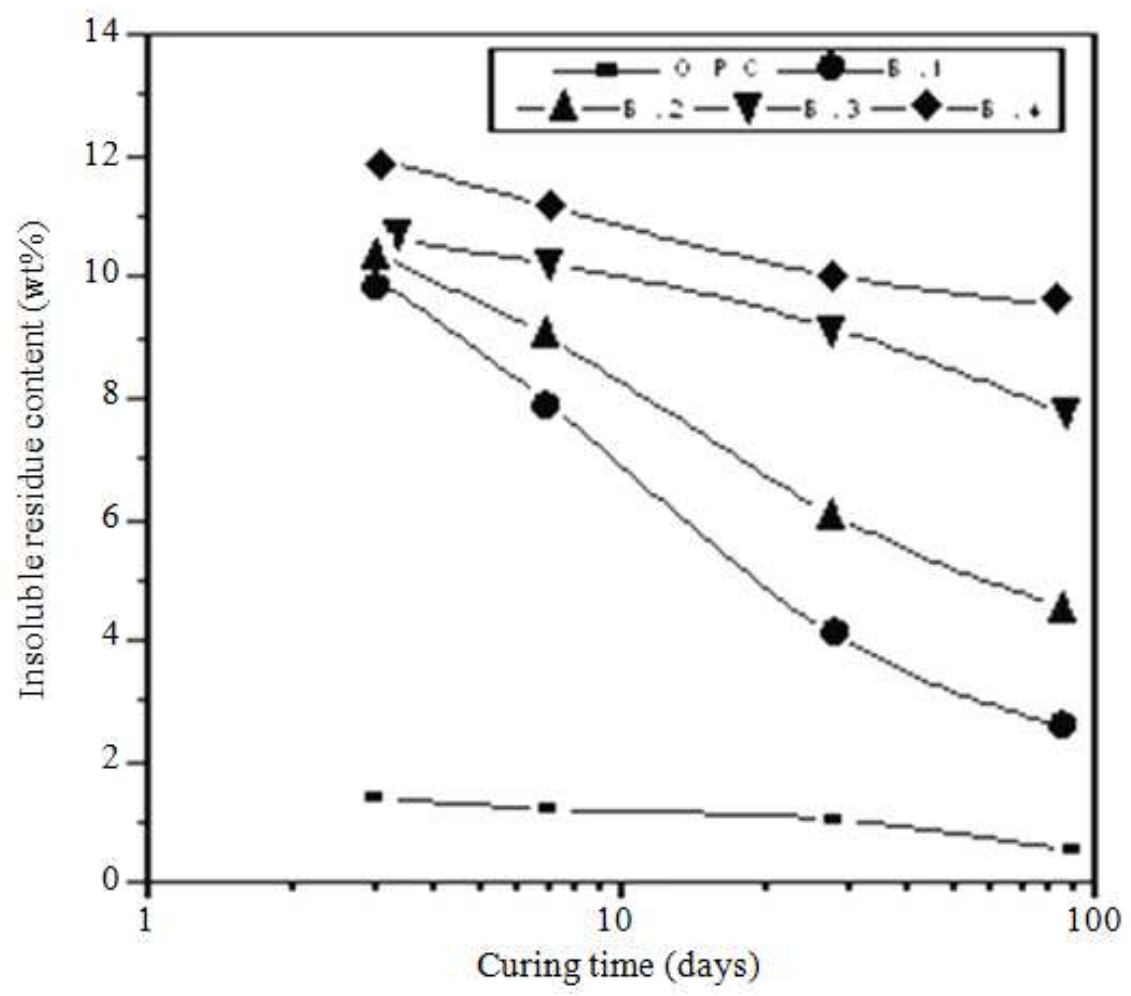

Fig. 9. Insoluble residue content of OPC and Pozzolanic cement as a function of curing time 


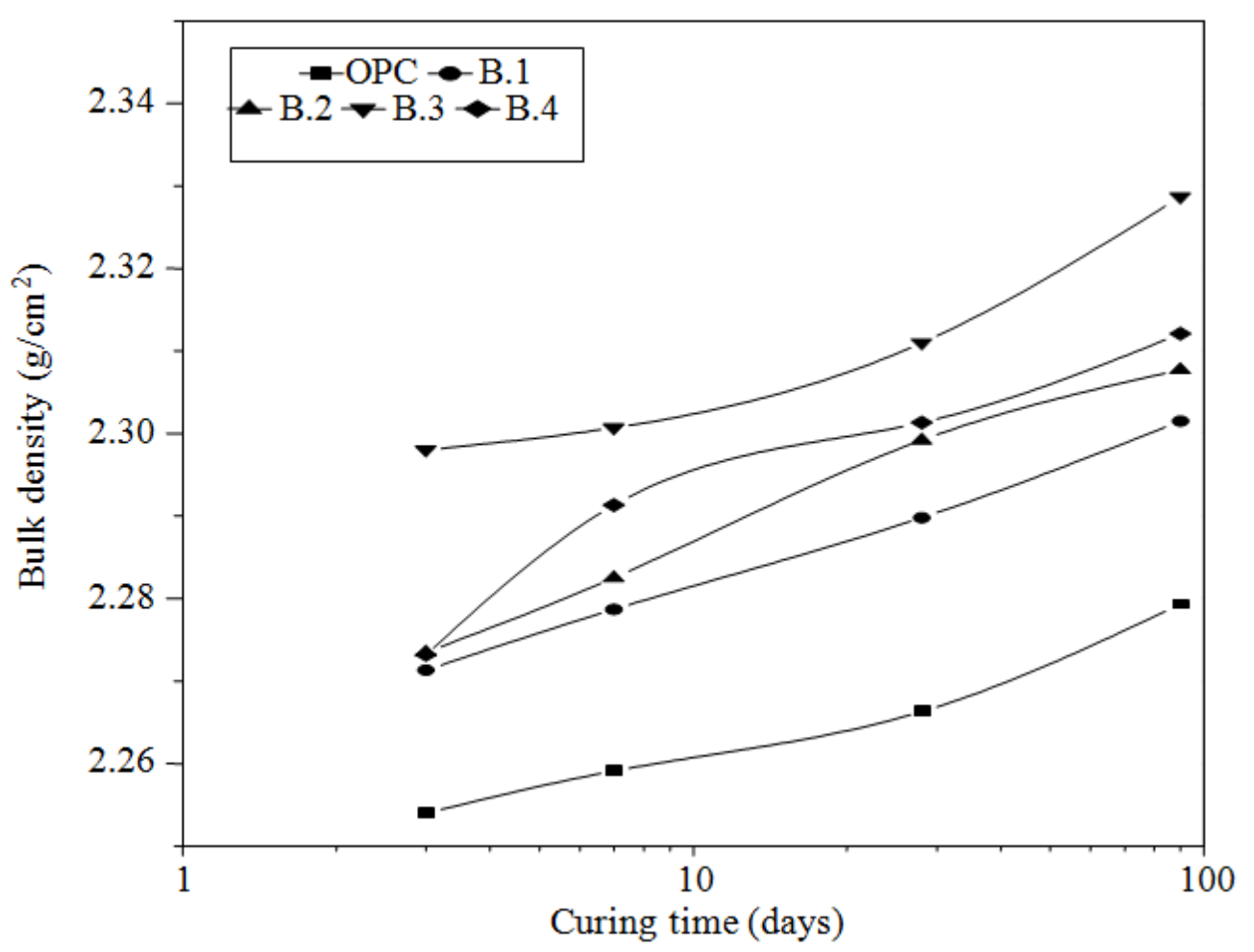

Fig. 10. Bulk density of basalt cement pastes as a function of curing time

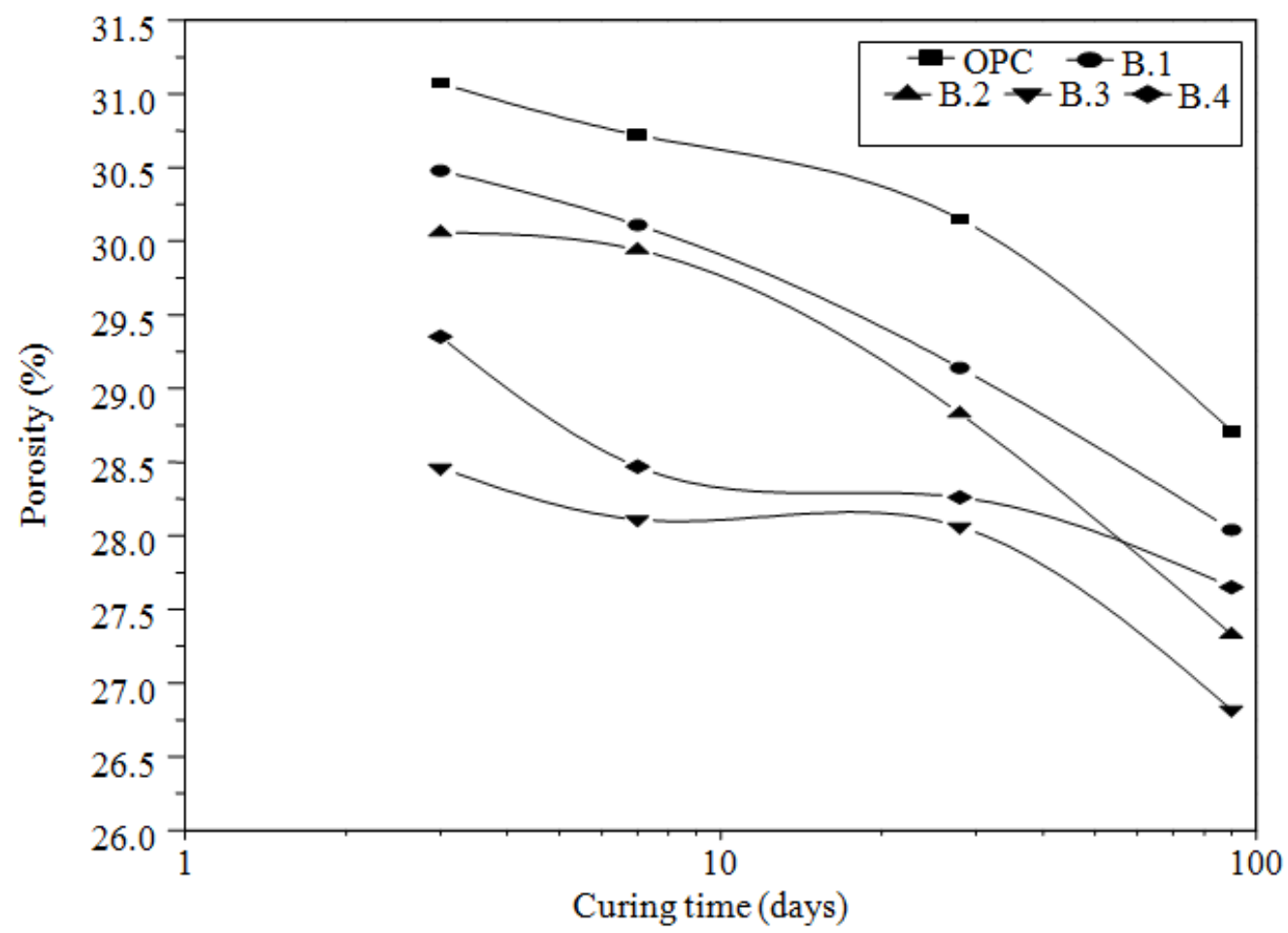

Fig. 11. Porosity of OPC and pozzolanic cement pastes as a function of curing time up to 90 days 


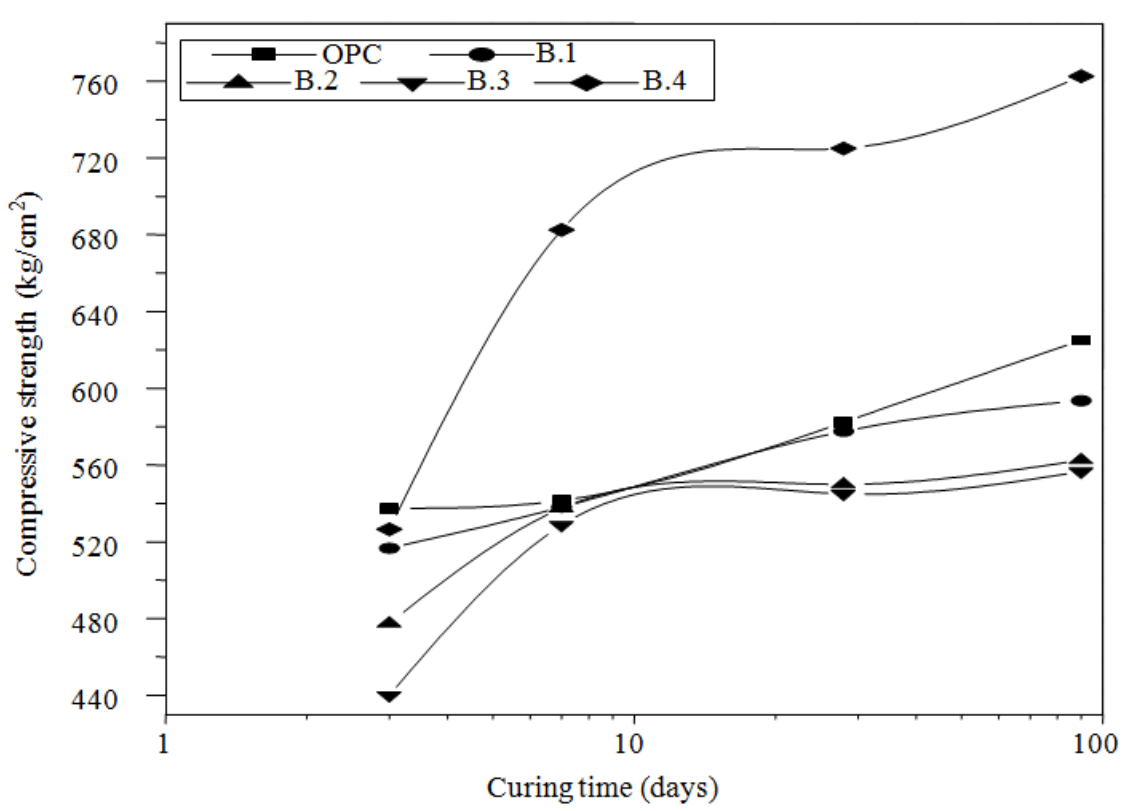

Fig. 12. Compressive strength of OPC and pozzolanic cement pastes as a function of curing time up to 90 days

This is mainly due to the liberation of free lime without any pozzolainc reaction therefore the compressive strength decreases. On the other side, the cement pastes containing $20 \mathrm{wt} \%$ basalt give higher values than those of ordinary as well as basalt filled cement pastes containing up to $15 \mathrm{wt} \%$. This may be due to the decrease of the liberated lime as shown from the results of free lime contents. The increase of free lime decreases the compressive strength. The free lime gives very low strength in comparison to that of $\mathrm{CSH}$.

\section{Conclusion}

The main conclusions derived from this study may be summarized as follows:

- Basalt pastes are need mixing water lower than OPC pastes

- Basalt has low pozzolanic activity at early ages and increases with time

- Basalt pastes have better physico-mechanical properties than OPC cement paste

- Basalt can be used as filled-pozzolanic material

\section{Acknowledgement}

We gratefully acknowledge to the Faculty of Science, Zagazig University and National Research Centre due to the support to this research.

\section{Funding Information}

This research was internally supported.

\section{Author's Contributions}

H. El-Didamony: Coordinated the data-analysis and contributed to the writing of the manuscript and designed the research plan and organized the study.

I.M. Helmy: coordinated the data-analysis and contributed to the writing of the manuscript and designed the research plan and organized the study.

Randa M. Osman: Participated in all experiments, coordinated the data-analysis, contributed to the writing of the manuscript and coordinated the mouse work.

A.M. Habboud: Participated in all experiments, coordinated the data-analysis and contributed to the writing of the manuscript and designed the research plan and organized the study.

\section{Ethics}

This article is original and contains unpublished material. The corresponding author confirms that all of the other authors have read and approved the manuscript and no ethical issues involved.

\section{References}

ASTM, 2006. Standard test method for normal consistency of hydraulic cement. ASTM Standards,

Binic, H., O. Aksogan, A.H. Sevinc and A. Kucukonder, 2014. Mechanical and radioactivity shielding performances of mortars made with colemanite, barite, ground basaltic pumice and ground blast furnace slag. Construct. Build. Mater., 50: 177-83. DOI: 10.1016/j.conbuildmat.2013.09.033 
Binici, H., O. Aksogan, I.H. Cagatay, M. Tokyay and E. Emsen, 2007a. The effect of particle size distribution on the properties of blended cements incorporating GGBFS and Natural Pozzolan (NP). Powder Technol., 177: 140-147. DOI: $10.1016 /$ j.powtec.2007.03.033

Binici, H., H. Temiz and M.M. Kose, 2007b. The effect of fineness on the properties of the blended cements incorporating ground granulated blast furnace slag and ground basaltic pumice. Construct. Build. Mater., 21: 1122-1128. DOI: 10.1016/j.conbuildmat.2005.11.005

Binici, H., O. Aksogan, E.B. Gorur, H. Kaplan and M.N. Bodur, 2008. Performance of ground blast furnace slag and ground basaltic pumice concrete against seawater attack. Construct. Build. Mater., 22: $1515-1526$.

DOI: 10.1016/j.conbuildmat.2007.03.024

Binici, H., S. Kapur, J. Arocena and H. Kaplan, 2012. The sulphate resistance of cements containing red brick dust and ground basaltic pumice with submicroscopic evidence of intra-pore gypsum and ettringite as strengtheners. Cement Concrete Composites, 34: 279-87.

DOI: 10.1016/j.cemconcomp.2011.10.001

Constantiner, D. and S. Diamond, 2003. Alkali release from feldspars into pore solutions. Cement Concrete Res., 33: 549-54.

DOI: 10.1016/S0008-8846(02)01001-3

De Weerdt, K., M.B. Haha, G. Le Saout, K.O. Kjellsen and H. Justnes et al., 2011. Hydration mechanisms of ternary Portland cements containing limestone powder and fly ash. Cement Concrete Res., 41: 279-291.

DOI: 10.1016/j.cemconres.2010.11.014

Ghrici, M., S. Kenai and M. Said-Mansour, 2007. Mechanical properties and durability of mortar and concrete containing natural pozzolana and limestone blended cements. Cement Concrete Composites, 29: 542-549.

DOI: 10.1016/j.cemconcomp.2007.04.009

Habert, G., N. Choupay, J.M. Montel, D. Guillaume and G. Escadeillas, 2008. Effects of the secondary minerals of the natural pozzolans on their pozzolanic activity. Cement Concrete Res., 38: 963-975. DOI: 10.1016/j.cemconres.2008.02.005

Hossain, K.M.A. and M. Lachemi, 2007. Strength, durability and micro-structural aspects of high performance volcanic ash concrete. Cement Concrete Res., 37: 759-766.

DOI: 10.1016/j.cemconres.2007.02.014
Hossain, K.M.A. and M. Lachemi, 2006. Performance of volcanic ash and pumice based blended cement concrete in mixed sulfate environment. Cement Concrete Res., 36: 1123-1133.

DOI: 10.1016/j.cemconres.2006.03.010

Hossain, K.M.A., 2005. High strength blended cement concrete incorporating volcanic ash: Performance at high temperatures. Cement Concrete Composites, 28: 535-545.

DOI: 10.1016/j.cemconcomp.2006.01.013

Jain, N., 2012. Effect of nonpozzolanic and pozzolanic mineral admixtures on the hydration behavior of ordinary Portland cement. Construct. Build. Mater., 27: 39-44.

DOI: 10.1016/j.conbuildmat.2011.08.006

Kelestemur, O. and B. Demirel, 2010. Corrosion behavior of reinforcing steel embedded in concrete produced with finely ground pumice and silica fume. Construct. Build. Mater., 24: 1898-1905. DOI: 10.1016/j.conbuildmat.2010.04.013

Laibao, L., Z. Yunsheng, Z. Wenhua, L. Zhiyong and Z. Lihua, 2013. Investigating the influence of basalt as mineral admixture on hydration and microstructure formation mechanism of cement. Construct. Build. Mater., 48: 434-440. DOI: 10.1016/j.conbuildmat.2013.07.021

Martinez-Reyes, J., R. Alavez-Ramirez, P. MontesGarcia and V. Jimenez-Quero, 2010. Mineralogical effect on the pozzolanic reactivity of a Mexican lacustrine soil. Construct. Build. Mater., 24: 2650-2657.

DOI: $10.1016 /$ j.conbuildmat.2010.04.059

Massazza, F., 2006. Pozzolana and pozzolanic cements. In: Lea's Chemistry of Cement and Concrete, Hewlett, P.C. (Ed.), Butterworth-Heinemann, Oxford, pp: 471-635.

Rahhal, V., V. Bonavetti, L. Trusilewicz, C. Pedrajas and R. Talero, 2012. Role of the filler on Portland cement hydration at early ages. Construct. Build. Mater., 27: 82-90.

DOI: 10.1016/j.conbuildmat.2011.07.021

Saraya, M.E.S., 2011. Study the pozzolanic activity of fresh basalt. J. Mater. Sci. Eng., 1: 40-50.

Shui, Z.H., R. Zhang, W. Chen and D.X. Xuan, 2010. Effects of mineral admixtures on the thermal expansion properties of hardened cement paste. Construct. Build. Mater., 24:1761-1767.

DOI: 10.1016/j.conbuildmat.2010.02.012

Siddique, R. and J. Klaus, 2009. Influence of metakaolin on the properties of mortar and concrete: a review. Applied Clay Sci., 43: 392-400.

DOI: 10.1016/j.clay.2008.11.007 
Uysal, M. and K. Yilmaz. 2011. Effect of mineral admixtures on properties of self-compacting concrete. Cement Concrete Composites, 33: 771-776. DOI: 10.1016/j.cemconcomp.2011.04.005

Uzal, B., L. Turanl, H. Yucel, M.C. Göncüoğlu and A. Çulfaz, 2010. Pozzolanic activity of clinoptilolite: a comparative study with silica fume, fly ash and a non-zeolitic natural pozzolan. Cement and Concrete Res., 40: 398-404.

DOI: $10.1016 /$ j.cemconres.2009.10.016
Uzal, B. and L. Turanl, 2012. Blended cements containing high volume of natural zeolites: Properties, hydration and paste microstructure. Cement Concrete Composites, 34:101-109. DOI: 10.1016/j.cemconcomp.2011.08.009

Yeau, K.Y. and E.K. Kim, 2005. An experimental study on corrosion resistance of concrete with ground granulate blast-furnace slag. Cement Concrete Res., 35:1391-1399.

DOI: $10.1016 /$ j.cemconres.2004.11.010 